\title{
Effects of C282Y, H63D, and S65C HFE gene mutations, diet, and life-style factors on iron status in a general Mediterranean population from Tarragona, Spain
}

\author{
Núria Aranda • Fernando E. Viteri • \\ Carme Montserrat • Victoria Arija
}

Received: 30 November 2009 / Accepted: 4 January 2010 / Published online: 28 January 2010

(C) The Author(s) 2010. This article is published with open access at Springerlink.com

\begin{abstract}
Mutations in the HFE gene result in iron overload and can produce hereditary hemochromatosis $(\mathrm{HH})$, a disorder of iron metabolism characterized by increased intestinal iron absorption. Dietary quality, alcoholism and other life-style factors can increase the risk of iron overload, especially among genetically at risk populations. Polymorphisms of the HFE gene (C282Y, H63D and $\mathrm{S} 65 \mathrm{C}$ ) were measured together with serum ferritin (SF), transferrin saturation (TS) and hemoglobin, to measure iron status, in randomly-selected healthy subjects living in the Spanish Mediterranean coast $(n=815 ; 425$ females, 390 males), 18 to 75 years of age. The intake of dietary components that affect iron absorption was calculated from 3-day dietary records. The presence of $\mathrm{C} 282 \mathrm{Y} / \mathrm{H} 63 \mathrm{D}$ compound heterozygote that had a prevalence of $2.8 \%$ in males and $1.2 \%$ in females was associated with an elevated TS and SF. No subject was homozygous for $\mathrm{C} 282 \mathrm{Y}$ or $\mathrm{S} 65 \mathrm{C}$. The $\mathrm{C} 282 \mathrm{Y}$ heterozygote, H63D heterozygote and homozygote and $\mathrm{H} 63 \mathrm{D} / \mathrm{S} 65 \mathrm{C}$ compound heterozygote genotypes were associated with increased TS relative to the wild type in the general population. These genotypes together with the alcohol and iron intake increase the
\end{abstract}

\footnotetext{
N. Aranda $\cdot$ C. Montserrat $\cdot$ V. Arija $(\triangle)$

IISPV, Universitat Rovira i Virgili,

Tarragona, Spain

e-mail: mariavictoria.arija@urv.cat

F. E. Viteri

Nutritional Sciences and Toxicology,

Morgan Hall, University of California,

Children's Hospital Oakland Research Institute (CHORI),

Oakland, USA

V. Arija

Institut de Investigació Jordi Gol (IDIAP),

Girona, Spain
}

indicators of iron status, while calcium intake decreases them. We did not observe any affect of the S65C heterozygote genotype on these levels. All the HFE genotypes except for the $\mathrm{S} 65 \mathrm{C}$ heterozygote together with the alcohol, iron and calcium intake affect the indicators of iron status. The C282Y/H63D compound heterozygote genotype has the higher phenotypic expression in our Spanish Mediterranean population.

Keywords Iron overload $\cdot \mathrm{HFE}$ gene $\cdot \mathrm{C} 282 \mathrm{Yvariant} \cdot \mathrm{H} 63 \mathrm{D}$ variant $\cdot \mathrm{S} 65 \mathrm{C}$ variant $\cdot$ Mediterranean diet

$\begin{array}{ll}\text { Abbreviation } \\ \text { HH } & \text { Hereditary hemochromatosis } \\ \text { FS } & \text { Serum ferritin } \\ \text { TS } & \text { Transferrin saturation } \\ \text { BMI } & \text { Body mass index } \\ \text { MLR } & \text { Multiple linear regression model }\end{array}$

\section{Background}

Iron overload can be associated with certain genetic mutations and environmental factors. The HFE gene, together with other biologically active compounds, regulates the intestinal absorption of iron $[1,2]$. There have been three common variants detected in this gene, C282Y, H63D and S65C, which have been related to the susceptibility to iron overload. Studies in Europe have reported the prevalence of the homozygous C282Y genotype as $<1.5 \%$ and that of the heterozygous genotype as $<29 \%$; the highest rates occur in northern Europe [3, 4]. Homozygotes and heterozygotes for the H63D mutation constitute $<8 \%$ and $<38.8 \%$, respectively, in the populations studied to-date 
in Europe [4]. These polymorphisms are most prevalent in southern Europe. The prevalence of the C282Y/H63D compound heterozygote is $<4 \%$ [4].

The prevalence of the $\mathrm{H} 63 \mathrm{D}$ in our population is elevated, being present in heterozygote form in $32.3 \%$ and in homozygote form in $4.8 \%$ [5]. The C282Y mutation is less prevalent, so far being found only in heterozygous form in 4.3\% of our population [4-6]. The S65C mutation is less well studied but, as well, has been associated with alterations in the mechanisms of intestinal iron absorption $[7,8]$. We have not detected any homozygous cases, and the heterozygous form is present in $2 \%$ of the population. The compound forms of these three mutations are present in $2.6 \%[5]$.

The biochemical phenotypic expression of the H63D (homozygote and heterozygote) and of the C282Y (heterozygotes) genotypes is much lower than that in the $\mathrm{C} 282 \mathrm{Y}$ homozygote or in the compound $\mathrm{C} 282 \mathrm{Y} /$ H63D genotypes $[9,10]$. Even though these genotypes do not have high penetration at the biochemical level, it is possible that body levels of iron in affected persons can be higher than normal, and be potential risks for some diseases. Several authors have postulated that levels of iron near the upper limit of normal are associated with pathological processes including cellular oxidation, cardiovascular disease and cancer [10-18]. However, these relations have not always been observed in populations, such being the case of the French studied in the SUVIMAX intervention study [19, 20].

Dietary quality, alcoholism and other life-style factors can increase the risk of iron overload, especially among genetically at risk populations [21, 22], and yet there are no data on these effects in our population. The main objective of this paper was to fill this gap.

\section{Methods}

The sample was randomly drawn from the local government census of three communities in the Mediterranean region of Tarragona (N.E. Spain). The sample consisted of individuals of Caucasian origin, stratified by age and gender, reflecting its distribution in the study area. Exclusion criteria were: inability to understand the characteristics of the study, suffering severe disease that would impair participation, pregnancy, or being within 6 months post-partum. The study was approved by the Ethics Committee of the Sant Joan University Hospital and the Jordi Gol Gorina Foundation.

Letters of invitation to participate in the study were sent to a total of 1,325 people. Willingness to participate was confirmed by phone call. If someone refused or could not be contacted following three different phone calls (at different times on different days), they were replaced by the next available candidate of the same age and sex on the list. A total of 815 healthy subjects (425 female, 390 males) between 18 and 75 years were studied.

All the individuals provided written informed consent according to the Declaration of Helsinki. Subjects selected for participation were interviewed and the following data were recorded: demographic characteristics, data on any current pathology, medications and iron supplements used in the last year, anthropometric measurements (height and weight) and life-style habits such as smoking, ingestion of alcoholic beverages, and physical activity. Food intake was evaluated using the diary recall method over three nonconsecutive days including a weekend or a holiday [23]. Body mass index (BMI) was calculated as weight/height squared.

A venous blood sample was drawn from subjects into two $10 \mathrm{ml}$. vacutainer tubes: one was containing EDTA for the measurement of the hematological profile and for DNA extraction, and the other without anticoagulant for serum biochemistry analyses. All the samples were extracted at the same time (between 8 and $8.30 \mathrm{~h}$ ) with the subjects having fasted since the previous evening.

C282Y (G845A), H63D (C187G) [24] and S65C (A193T) [7] mutations of the HFE gene were measured using the polymerase chain reaction (PCR). Absence of these three mutations defined the wild-type genotype.

Serum iron $(\mu \mathrm{mol} / \mathrm{L})$ and serum transferrrin $(\mathrm{g} / \mathrm{L})$ were measured using commercial kits (ITC Diagnostics and Biokit S.A., Barcelona). Serum ferritin (SF; $\mu \mathrm{g} / \mathrm{L}$ ) was measured immuno-turbidimetrically [25]. The transferrin saturation index was calculated as reported [26]. Since inflammation and infection can elevate SF levels, these were adjusted by C-reactive protein levels (CRP; Biokit S.A., Barcelona, Spain). Ferritin log transformed values (log-ferritin) were used in the statistical analyses because of its skewed distribution. Blood hemoglobin $(\mathrm{g} / \mathrm{dl})$ was measured in duplicate with a Coulter GENS analyzer (Coulter, Hialeah, FL).

The extraction and storage of blood samples followed a protocol established and accepted by international studies. The method for assessing habitual food intake (the dietary recall method) has been validated internationally and shown to be the method with the appropriate level of accuracy to enable assessments of nutritional status [27].

All data were analyzed using the SPSS package for Windows (version 17.0). $t$ Test was used for comparison of continuous data and Pearson's chi-square or Fisher's test to compare categorical data. Two multiple linear regression (MLR) models were applied to explain the effect of the genotypes on the measured values of iron status. TS was the dependent variable in one, and log-ferritin was the 
dependent variable in the other. The genetic variables were segregated into six groups: (a) C282Y heterozygotes; (b) H63D heterozygotes; (c) S65C heterozygotes; (d) H63D homozygotes; (e) C282Y/H63D compound heterozygotes and (f) H63D/S65C compound heterozygotes. Dummy variables were created with each of these six groups in order to compare each of them with the wild-type genotype. In both models the "ENTER" method was used for the dummy genetic variables (no/yes) and "STEPWISE" method for gender (female; male), age (years), BMI $\left(\mathrm{Kg} / \mathrm{m}^{2}\right)$, smoking habit (cigarettes/day), level of physical activity (h/week), Iron supplements intake (no, yes), and the dietary variables related to iron metabolism, i.e., energy (Joules), iron (mg/day), proteins (g/day), fiber (g/day), calcium (mg/day), vitamin C (mg/day), and alcohol intake (g/day). Subsequently, these same models were applied separately for each gender and, as such, gender was not entered as a variable in the analysis. The level of statistical significance was set at $p<0.05$.

\section{Results}

Table 1 contains the means of the TS and FS distribution segregated according to HFE genotypes and gender. In males, the mean values of TS were significantly elevated in the $\mathrm{C} 282 \mathrm{Y} / \mathrm{H} 63 \mathrm{D}$ compound heterozygotes relative to wild type. In females, the mean TS was also elevated in the C282Y heterozygotes, H63D heterozygotes, and homozygotes and again in the $\mathrm{C} 282 \mathrm{Y} / \mathrm{H} 63 \mathrm{D}$ compound heterozygotes genotypes relative to wild type. When the weighted mean of TS of all subjects with any HFE mutation $(44.5 \%$ males and $47.2 \%$ females) is compared with that of the wild-type genotype, the subjects with these mutations, independent of gender, showed higher concentrations of TS. In contrast, we did not observe statistically significant differences in serum ferritin levels (Table 1).

Three men and 22 women were taking iron supplements, and had SF of $37.8 \mu \mathrm{g} / \mathrm{L}$ and TS of $27.1 \%$ compared with SF of $102.7 \mu \mathrm{g} / \mathrm{L}$ and $\mathrm{TS}$ of $34.1 \%$ in the

Table 1 Biochemical parameters of iron segregated with respect to HFE genotypes and gender in the study population

\begin{tabular}{|c|c|c|c|c|c|c|c|c|c|c|}
\hline \multirow[t]{2}{*}{ Subjects $(\%)$} & \multicolumn{3}{|c|}{ HFE genotype } & \multirow{2}{*}{$\begin{array}{l}\text { Hemoglobin } \\
(\mathrm{g} / \mathrm{dl}) \\
\text { Mean (SD) }\end{array}$} & \multicolumn{2}{|c|}{ Transferrin saturation $(\%)$} & \multicolumn{4}{|l|}{ Serum ferritin $(\mu \mathrm{g} / \mathrm{L})$} \\
\hline & $\mathrm{C} 282 \mathrm{Y}$ & H63D & $\mathrm{S} 65 \mathrm{C}$ & & Mean (SD) & $>45(\%)^{\mathrm{a}}$ & Geometric mean $(\mathrm{SD})^{\mathrm{b}}$ & $>100(\%)^{\mathrm{a}}$ & $>150(\%)^{\mathrm{a}}$ & $>200(\%)^{\mathrm{a}}$ \\
\hline \multicolumn{11}{|l|}{ Males, $n=390$} \\
\hline 55.5 & $-1-$ & $-1-$ & $-1-$ & $15.3(.9)$ & $37.7(20.8)$ & 22.7 & $105.6(2)$ & 59.5 & 27.9 & 16.7 \\
\hline 2.3 & $-1-$ & $-1-$ & $+/-$ & $15.4(1.1)$ & $40.9(12.2)$ & 33.3 & $76.9(2.5)$ & 44.4 & 22.2 & 11.1 \\
\hline 3.9 & $+/-$ & $-1-$ & $-1-$ & $15.5(1.0)$ & $41.9(14.5)$ & 26.7 & $99.8(2.2)$ & 73.3 & 46.7 & 13.3 \\
\hline 31.6 & $-1-$ & $+/-$ & $-1-$ & $15.5(1.0)$ & $39.7(13.3)$ & 28.5 & $109.9(2.2)$ & 64.2 & 36.6 & $25.2 *$ \\
\hline 3.3 & $-1-$ & $+/+$ & $-1-$ & $15.2(1.0)$ & $40.0(20.9)$ & 38.5 & $101.6(2.5)$ & 84.6 & 38.5 & 15.4 \\
\hline 0.5 & $-1-$ & $+/-$ & $+/-$ & $16.1(.9)$ & $65.9(42.9)$ & 50 & $187.8(1.7)$ & 100 & 50 & 50 \\
\hline 2.8 & $+/-$ & $+/-$ & $-1-$ & $15.7(.9)$ & $53.4(19)^{*}$ & $63.6 * *$ & $143.5(2.6)$ & 63.6 & $54.5^{*}$ & 36.4 \\
\hline 100 & & & & $15.4(1.0)$ & $39.3(18.5)$ & 26.7 & $106.9(2.1)$ & 62.1 & 32.4 & 19.7 \\
\hline $44.5^{\mathrm{c}}$ & & & & $15.5(1.0)$ & $41.2(15.2)^{*}$ & $31.8^{*}$ & $108.5(2.2)$ & 65.9 & $38.2 *$ & $23.7 *$ \\
\hline \multicolumn{11}{|c|}{ Femalesn $=425$} \\
\hline 52.8 & $-/-$ & $-1-$ & $-1-$ & $13.3(1.0)$ & $26.7(11.2)$ & 6.3 & $33.1(2.3)$ & 9 & 4.5 & 2.2 \\
\hline 1.7 & $-1-$ & $-1-$ & $+/-$ & $12.9(1.1)$ & $26.5(11)$ & 0 & $28.1(2.5)$ & 14.3 & 0 & 0 \\
\hline 4.7 & $+/-$ & $-1-$ & $-1-$ & $13.9(1.2)$ & $32.7(11.9)^{*}$ & 10.5 & $48.6(2.1)$ & 15.8 & 5.3 & 5.3 \\
\hline 32.8 & $-1-$ & $+/-$ & $-1-$ & $13.4(.9)$ & $30.6(14.5) * *$ & 11.5 & $37.2(2.1)$ & 11.6 & 2.9 & 2.2 \\
\hline 6.1 & $-1-$ & $+/+$ & $-1-$ & $13.9(.9)$ & $34.9(13.1)^{* *}$ & 15.4 & $37.7(1.7)$ & 0 & 0 & 0 \\
\hline 0.7 & $-1-$ & $+/-$ & $+/-$ & $13.9(.7)$ & $26.8(10.3)$ & 0 & $54.6(1.7)$ & 0 & 0 & 0 \\
\hline 1.2 & $+/-$ & $+/-$ & $-1-$ & $13.9(.8)$ & $40.5(5.4) * *$ & 20 & $47.2(2.2)$ & 20 & 20 & 0 \\
\hline 100 & & & & $13.4(1.0)$ & $28.9(12.7)$ & 8.7 & $35.6(2.2)$ & 10 & 4 & 2.4 \\
\hline $47.2^{\mathrm{c}}$ & & & & $14.2(9.1)$ & $31.4(13.8)^{* * *}$ & $11.6^{*}$ & $38.3(2.1)$ & 10.6 & 3 & 2 \\
\hline
\end{tabular}

$(-)$ indicates HFE wild type, $(+)$ indicates mutated allele, $S D$ standard deviation

${ }^{*} p<0.05 * * p<0.01 * * * p<0.001$ vs versus wild type ( $t$ student, $\chi^{2}$ Pearson's or Fisher's test)

${ }^{\text {a }}$ Subjects $(\%)$

${ }^{\mathbf{b}}$ Geometric mean (SD) antilog values

${ }^{\mathrm{c}}$ Subjects with mutations in HFE gene 
rest of the study sample $(p<0.001$ and $p<0.033$ for SF and TS, respectively).

When diet and other life style variables besides HFE polymorphisms were included in an analysis using MLR in order to determine the influence of HFE mutations on TS and SF values (Table 2), the TS was found significantly increased with all the HFE genotypes except for the S65C heterozygotes. The following were positively related in the model: iron intake, alcohol intake, tobacco habit, and male gender, while calcium intake was inversely related. Table 2 only shows the significant results. The same MLR model applied only to females showed a significant increase in TS in the presence of the $\mathrm{C} 282 \mathrm{Y}$ heterozygote $(\beta, 6.43$; SE, $3.03 ; p, 0.035)$, H63D heterozygote $(\beta, 4.13$; SE, 1.39 ; $p, 0.003)$ and homozygote $(\beta, 8.43 ; \mathrm{SE}, 2.61 ; p, 0.001)$ and the $\mathrm{C} 282 \mathrm{Y} / \mathrm{H} 63 \mathrm{D}$ compound heterozygote genotypes $(\beta, 13.11$; SE, $5.59 ; p, 0.02)$. Tobacco habit was positively related $(\beta, 0.21 ; \mathrm{SE}, 0.08 ; p, 0.013)$. The same MLR model applied only to males showed that TS was increased significantly with the C282Y/H63D ( $\beta, 13.21$; SE, 6.59; $p, 0.046)$ and $\mathrm{H} 63 \mathrm{D} / \mathrm{S} 65 \mathrm{C}(\beta, 27.83$; SE, $12.98 ; p, 0.033)$ compound heterozygotes. Iron intake was positively related to TS $(\beta, 0.97 ; \mathrm{SE}, 0.24 ; p<0.001)$ whether the 22 women and three men that were ingesting iron supplements were included or not in the analysis (data not shown).

In the overall population sample, log serum ferritin (logFS) was significantly increased in the presence of the $\mathrm{C} 282 \mathrm{Y} / \mathrm{H} 63 \mathrm{D}$ compound mutations, and in relation to alcohol consumption, age and male gender. Log-SF was negatively related to calcium intake. MLR applied only to females showed log-SF significantly increased with smoking $(\beta, 0.01 ; \mathrm{SE}, 0.005 ; p, 0.003 ; \% \mathrm{v}, 1.01)$ and increasing age $(\beta, 0.02 ; \mathrm{SE}, 0.002 ; p<0.001 ; \% \mathrm{v}, 2.02)$, and decreased with the intake of calcium $(\beta,-3.5 \mathrm{e}-4$; SE, $1.15 \mathrm{e}-4$; $p, 0.002 ; \% \mathrm{v}, 0.04)$. In males, log-FS increased significantly with $\mathrm{C} 282 \mathrm{Y} / \mathrm{H} 63 \mathrm{D}$ compound genotypes $(\beta, 0.44$; SE, $0.24 ; p, 0.05, \% \mathrm{v}, 55.27)$ and with the consumption of alcohol ( $\beta, 0.008$; SE, $0.002 ; p<0.001 ; \% \mathrm{v}, 0.8)$, and decreased with the consumption of calcium $(\beta,-2.5 \mathrm{e}-4$; SE, $1.06 \mathrm{e}-4 ; p, 0.015 ; \% \mathrm{v}, 0.02)$. The influence of these variables on the population with the wild type in HFE genes independent of gender did not reach significance. Consistently, however, calcium and fiber intake correlate negatively with both TS and SF among males with HFE polymorphisms. Again, the exclusion of the three men and the 22 females ingesting iron supplements did not change the results (data not shown).

\section{Discussion}

Many studies have analyzed the relation between HFE mutations and iron status $[9,28-36]$. There are a few other recent studies that explore external factors that interact with HFE mutations in modifying the phenotypic expression in indicators of iron status of the genetic HFE makeup [37,

Table 2 Effect of mutations in the HFE gene on biochemical levels of transferrin saturation and serum ferritin (log-FS) in the overall population sample $(n=815)$

\begin{tabular}{|c|c|c|c|c|c|c|c|}
\hline & \multicolumn{3}{|c|}{ Transferrin saturation } & \multicolumn{4}{|c|}{ Serum ferritin (log-FS) } \\
\hline & $\beta$ coeff. & SE & p-value & $\beta$ coeff. & SE & $p$ value & $\% \mathrm{v}$ \\
\hline $\mathrm{C} 282 \mathrm{Y} / \mathrm{WT}$ & 5.75 & 2.75 & 0.037 & 0.19 & 0.12 & 0.12 & \\
\hline $\mathrm{H} 63 \mathrm{D} / \mathrm{WT}$ & 3.00 & 1.24 & 0.015 & 0.06 & 0.05 & 0.261 & \\
\hline $\mathrm{S} 65 \mathrm{C} / \mathrm{WT}$ & 0.77 & 4.05 & 0.850 & -0.16 & 0.18 & 0.361 & \\
\hline H63D /H63D & 7.26 & 2.66 & 0.006 & 0.01 & 0.11 & 0.888 & \\
\hline C282Y/H63D & 16.4 & 4.2 & $<0.001$ & 0.32 & 0.18 & 0.049 & 37.7 \\
\hline $\mathrm{H} 63 \mathrm{D} / \mathrm{S} 65 \mathrm{C}$ & 18.28 & 7.73 & 0.018 & 0.54 & 0.34 & 0.117 & \\
\hline Gender (female; male) & 8.04 & 1.27 & $<0.001$ & 0.97 & 0.05 & $<0.001$ & 163.7 \\
\hline Age (years) & & & & 0.01 & 0.002 & $<0.001$ & 1.01 \\
\hline Iron (mg/day) & 0.58 & 0.17 & 0.001 & & & & \\
\hline Calcium (mg/day) & -0.004 & 0.002 & 0.042 & $-2.5 \mathrm{e}^{-4}$ & $7.9 \mathrm{e}^{-5}$ & 0.002 & 0.02 \\
\hline Alcohol (g/day) & 0.069 & 0.03 & 0.037 & 0.007 & 0.001 & $<0.001$ & 0.7 \\
\hline \multirow[t]{3}{*}{ Tobacco (cig/day) } & 0.17 & 0.06 & 0.007 & & & & \\
\hline & \multicolumn{3}{|c|}{$R_{\mathrm{c}}^{2}=15.2$} & \multicolumn{4}{|c|}{$R_{\mathrm{c}}^{2}=42.4$} \\
\hline & \multicolumn{3}{|c|}{$\mathrm{F}_{11.756}=14.9 p<0.001$} & \multicolumn{4}{|c|}{$\mathrm{F}_{10.749}=56.79 p<0.001$} \\
\hline
\end{tabular}

Serum ferritin adjusted for $\mathrm{C}$ reactive protein and $\log$ transformed (log-FS). Adjusted for gender (female/male), age (years), BMI (Kg/ $\left.\mathrm{m}^{2}\right)$, energy (Joules), diet iron (mg/day), proteins (g/day), fiber (g/day), calcium (mg/day), vitamin C (mg/day), alcohol (g/day), smoking habit (cigarettes/day), level of physical activity (h/week) and iron supplements intake (no, yes)

$W T$ wild type, $S E$ standard error, $\% v$ percentage of variation 
38]. However, to our knowledge, the present study is the only one to evaluate the impact of the three common variants of the HFE gene, the diet and life style variables on indicators of iron status in a sample representative of the general Spanish Mediterranean population. The prevalence of $\mathrm{S} 65 \mathrm{C}$ variant in a general population and its relation with iron status has scarcely been investigated. The $\mathrm{S} 65 \mathrm{C}$ heterozygote genotype is infrequent in our and in most European populations, and, contrary to Mura et al's. [7] results appear to have little influence on iron status based on our MLR although a larger sample size is needed to support that.

The different effects of HFE mutations on TS and SF found in our MLR analyses concur with those observed by other investigators [28,39] in showing that individual carriers of heterozygous HFE mutations have a greater susceptibility to increased TS, and possibly of iron overload (Table 2) but to levels that are not associated with organ damage [40, 41]. The influence of single HFE heterozygous or even homozygous mutations for H63D on SF is not significant independent of gender (Table 2). However, the compounded heterozygous $\mathrm{C} 282 \mathrm{Y} / \mathrm{H} 63 \mathrm{D}$ genotype displays the most significant elevation of TS and SF values, in both women, and men. The phenotypic expression of the compounded heterozygous mutations involving the H63D mutation suggests an important role in expression or penetrance of the other mutations. The H63D variant has a lower effect on iron status, but its repercussion is very important due to its elevated frequency $(38.2 \%)$ [5, 42]. As in our population, an elevated prevalence of this mutation has been observed in other populations in the southern Europe [10].

It is interesting to note that the phenotypic expression of H63D homozygote, $\mathrm{C} 282 \mathrm{Y}$ and H63D heterozygote genotypes appear significantly only in women, suggesting HFE-gender interactions that should be explored further. The MLR models used in the analysis of our data enabled us to estimate the effect of HFE mutations on the levels of iron in our ostensibly healthy general population, independent of the contributions of diet and other life-style factors. In the overall population the compound genotypes are associated with a $16.4 \%$ $(\mathrm{C} 282 \mathrm{Y} / \mathrm{H} 63 \mathrm{D})$ and $18.3 \%(\mathrm{H} 63 \mathrm{D} / \mathrm{S} 65 \mathrm{C})$ increase in the TS concentrations relative to the subjects with wild type HFE. Also, $37.7 \%$ of the variation in serum ferritin concentration is explained by the heterozygous compound $\mathrm{C} 282 \mathrm{Y} / \mathrm{H} 63 \mathrm{D}$.

It is important to note that elevations in TS are more evident in men with HFE compound polymorphisms involving H63D variant than elevations in SF. Organ damage associated with hemochromatosis occurs only when both TS and SF are significantly elevated, the risk of which appears to be somewhat higher in these cases [4].
Unfortunately, the small number of cases limits the strength of our interpretations.

Based on the TS distributions an important percentage of our subjects $(6.3 \%$ of females and $22.7 \%$ of males) with the wild-type genotype as well as those with the C282Y, H63D, and $\mathrm{S} 65 \mathrm{C}$ genotypes have elevated values of TS $(>45 \%)$ and SF (between 110 and $200 \mu \mathrm{g} / \mathrm{L}$ in $2.8 \%$ of females, and between 200 and $300 \mu / \mathrm{L}$ in $7.4 \%$ of males). These results are higher than those found in a study carried out in a Danish male general population [38], and indicate that, as is known, there are other contributory factors in iron homeostasis not discussed in this paper but that can significantly affect the indicators of iron nutrition with respect to the HFE mutations in our population. We observed that dietary factors modulated the values of SF and TS in the expected manner and could, increase or decrease iron absorption and body iron (total iron intake increased and calcium decreased TS and SF values). However, dietary heme iron intake did not enter significantly into the equation (data not shown). This contrast with several reports suggesting that heme iron ingestion affect iron status and absorption in individuals with HFE mutations [34, 38, 43], however heme iron intake in our population was moderate (mean, $3.6 \mathrm{mg} /$ day). It would appear that there is a decrease in the control of iron absorption in subjects heterozygous for C282Y [44], allowing its absorption from diets rich in bioavailable iron. We do not know if this mechanism applies equally in other HFE mutations [10, 45, 46]. In agreement with other investigations [38, 47, 48], alcohol consumption reported by our population resulted in increased TS and SF values.

The combined effect of diet and mutations of the HFE gene suggests prudence in the politics of iron fortification of foods given that our Mediterranean diet is a good source of bio-available iron [49] inspite of controversies on this issue. On the other hand, the consistent lower TS and SF related to the intake of dietary calcium and fiber among males with HFE mutations may be considered a recommended dietary intervention.

In conclusion, the $\mathrm{C} 282 \mathrm{Y} / \mathrm{H} 63 \mathrm{D}$ compound heterozygote genotype is associated with an increase in TS and SF values compared to the wild type. The $\mathrm{C} 282 \mathrm{Y}$ heterozygote, H63D heterozygote and homozygote and H63D/S65C compound genotypes are related to increase in TS, but do not affect SF levels. The S65C heterozygote genotype does not significantly modify TS and SF. There is an interaction between the phenotypic manifestation on TS and SF of HFE mutations and gender. Iron intake as well as alcohol consumption increase, and dietary calcium and fiber cause a decrease in the indicators of iron status in the population, some effects differing by gender. The high prevalence of HFE mutations in our population together with the high bio-availability of iron in our Mediterranean diet calls for 
prudence in introducing measures aimed at increasing iron intake in all the population. High calcium and fiber intakes and abstinence from alcohol should be recommended for males with HFE mutations. Studies with larger samples should explore further these results.

Acknowledgments This study was supported by grants from the Instituto de Salud Carlos III, Fondo de Investigación Sanitaria, Ministerio de Sanidad y Consumo, Madrid, Spain (PI021131); a grant to our research group in "Nutrition and Public Health" (Generalitat de Catalunya 2009SGR-358) and by NIH National Center on Minority Health and Health Disparities grant IP60MD000222-03 (for Dr.Viteri).

Open Access This article is distributed under the terms of the Creative Commons Attribution Noncommercial License which permits any noncommercial use, distribution, and reproduction in any medium, provided the original author(s) and source are credited.

\section{References}

1. Feder JN, Gnirke A, Thomas W, Tsuchihashi Z, Ruddy DA, Basava A et al (1996) A novel MHC class-I like gene is mutated in patients with hereditary haemochromatosis. Nat Genet 13:399408. doi:10.1038/ng0896-399

2. Feder JN, Tsuchihashi Z, Irrinki A, Lee VK, Mapa FA, Morikang E et al (1997) The hemochromatosis founder mutation in HLA-H disrupts beta-2-microglobulin interaction and cell surface expression. J Biol Chem 272:14025-14028

3. Merryweather-Clarke AT, Pointon JJ, Jouanolle AM, Rochette J, Robson KJ (2000) Geography of HFE C282Y and H63D mutations. Genet Test 4:183-198. doi:10.1089/10906570050114902

4. Hanson EH, Imperatore G, Burke W (2001) HFE gene and hereditary hemochromatosis: a HuGE review. Human Genome Epidemiology. Am J Epidemiol 154:193-206

5. Aranda N, Viteri FE, Fernandez-Ballart J, Murphy M, Arija V (2007) Frequency of the hemochromatosis gene (HFE) $282 \mathrm{C}->\mathrm{Y}$, $63 \mathrm{H}->\mathrm{D}$, and $65 \mathrm{~S}->\mathrm{C}$ mutations in a general Mediterranean population from Tarragona, Spain. Ann Hematol 86:17-21. doi:10.1007/s00277-006-0179-0

6. Merryweather-Clarke AT, Pointon JJ, Shearman JD, Robson KJ (1997) Global prevalence of putative haemochromatosis mutations. J Med Genet 34:275-278

7. Mura C, Raguenes O, Férec C (1999) HFE mutations analysis in 711 hemochromatosis probands: evidence for $65 \mathrm{~S} \rightarrow \mathrm{C}$ implications in mild form of hemochomatosis. Blood 93:2502-2505

8. Holmströn P, Marmur J, Eggertsen G, Gafvels M, Stal P (2002) Mild iron overload in patients carrying the HFE $65 \mathrm{~S} \rightarrow \mathrm{C}$ gene mutation: a retrospective study in patients with suspected iron overload and healthy controls. Gut 51:723-730

9. Andersen RV, Tybjaerg-Hansen A, Appleyard M, Birgens H, Nordestgaard BG (2004) Hemochromatosis mutations in the general population: iron overload progression rate. Blood 103:2914-1919. doi:10.1182/blood-2003-10-3564

10. Beutler E (2006) Hemochromatosis: genetics and pathophysiology. Annu Rev Med 57:331-347. doi:10.1146/annurev.med.57.1213 04.131310

11. Sullivan JL (1981) Iron and the sex difference in heart disease risk. Lancet 1:1293-1294

12. Araujo JA, Romano EL, Brito BE, Parthé V, Romano M, Bracho $M$ et al (1995) Iron overload augments the development of atherosclerotic lesions in rabbits. Arterioscler Thromb Vasc Biol 15:1172-1180
13. Weinberg ED (1996) The role of iron in cancer. Eur J Cancer Prev 5:19-36

14. Tuomainen TP, Punnonen K, Nyyssönen K, Salonen JT (1998) Association between body iron stores and the risk of acute myocardial infarction in men. Circulation 97:1461-1466

15. Huang $X$ (2003) Iron overload and its association with cancer risk in humans: evidence for iron as a carcinogenic metal. Mutat Res 533:153-171

16. Yuan XM, Li W (2003) The iron hypothesis of atherosclerosis and its clinical impact. Ann Med 35:578-591

17. Robinson JP, Johnson VL, Rogers PA, Houlston RS, Maher ER, Bishop DT et al (2005) Evidence for an Association between Compound Heterozygosity for Germ Line Mutations in the Hemochromatosis (HFE) Gene and Increased Risk of Colorectal Cancer. Cancer Epidemiol Biomarkers Prev 14:1460-1463. doi:10.1158/1055-9965.EPI-04-0672

18. Yuan XM, Li W (2008) Iron involvement in multiple signaling pathways of atherosclerosis: a revisited hypothesis. Curr Med Chem 15:2157-2172

19. Galan P, Noisette N, Estaquio C, Czernichow S, Mennen L, Renversez JC et al (2006) Serum ferritin, cardiovascular risk factors and ischaemic heart diseases: a prospective analysis in the SU.VI.MAX (SUpplementation en VItamines et Mineraux AntioXydants) cohort. Public Health Nutr 9:70-74

20. Hercberg S, Estaquio C, Czernichow S, Mennen L, Noisette N, Bertrais S et al (2005) Iron status and risk of cancers in the SU.VI. MAX cohort. J Nutr 135:2664-2668

21. Burke W, Imperatore G, Reyes M (2001) Iron deficiency and iron overload: effects of diet and genes. Proc Nutr Soc 60:73-80

22. Fletcher LM, Powell LW (2003) Hemochromatosis and alcoholic liver disease. Alcohol 30:131-136

23. Bingham S, Nelson M (1991) Assessment of food consumption and nutrient intake. In: Margetts $\mathrm{B}$, Nelson $\mathrm{M}$ (eds) Design concepts in nutritional epidemiology. Oxford University Press, New York

24. Jouanolle AM, Fergelot P, Gandon G, Yaouanq J, Le Gall JY, David V (1997) A candidate gene for hemochromatosis: frequency of the $282 \mathrm{C} \rightarrow \mathrm{Y}$ and $63 \mathrm{H} \rightarrow \mathrm{D}$ mutations. Hum Genet 100:544-547

25. Gomez F, Simo JM, Camps J, Clivillé X, Bertran N, Ferré N et al (2000) Evaluation of a particle-enhanced turbidimetric immunoassay for the measurement of ferritin: application to patients participating in an autologous blood transfusion program. Clin Biochem 33:191-196

26. Fairbanks VF, Klee GG (1999) Biochemical aspects of haematology. In: Burtis CA, Ashwood ER (eds) Tietz textbook of clinical chemistry, 3rd edn. Saunders, Philadelphia, pp 1698-1705

27. Beaton GH, Milner J, Corey P, McGuire V, Cousins M, Stewart E et al (1979) Sources of variance in 24-hour dietary recall data: implications for nutrition study design and interpretation. Am J Clin Nutr 32:2546-2559

28. Distante S, Berg JP, Lande K, Haug E, Bell H (1999) High prevalence of the hemochromatosis-associated Cys282Tyr HFE gene mutation in a healthy Norwegian population in the city of Oslo and its phenotypic expression. Scand J Gastroenterol 34:529-534

29. Jackson HA, Carter K, Darke C, Guttridge MG, Ravine D, Hutton RD et al (2001) HFE mutations, iron deficiency and overload in 10, 500 blood donors. Br J Haematol 114:474-484

30. Fox CJ, Cullen DJ, Knuiman MW, Cumpston GN, Divitini ML, Rossi E et al (2002) Effects of body iron stores and haemochromatosis genotypes on coronary heart disease outcomes in the Busselton health study. J Cardiovasc Risk 9:287-293

31. Delatycki MB, Allen KJ, Nisselle AE, Collins V, Metcalfe S, du Sart D et al (2005) Use of community genetic screening to prevent HFE-associated hereditary haemochromatosis. Lancet 366:314 316. doi:10.1016/S0140-6736(05)63012-7 
32. Adams PC, Reboussin DM, Barton JC, McLaren CE, Eckfeldt JH, McLaren GD et al (2005) Hemochromatosis and iron-overload screening in a racially diverse population. $N$ Engl $J$ Med 352:1769-1778. doi:10.1056/NEJMoa041534

33. Cade JE, Moreton JA, O'Hara B, Greenwood DC, Moor J, Burley VJ, Kukalizch K, Bishop DT, Worwood M (2005) Diet and genetic factors associated with iron status in middle-aged women. Am J Clin Nutr 82:813-820

34. Greenwood DC, Cade JE, Moreton JA, O'Hara B, Burley VJ, Randerson-Moor JA et al (2005) HFE genotype modifies the influence of heme iron intake on iron status. Epidemiology $16: 802-805$

35. Rossetti MV, Méndez M, Afonso S, Gerez E, Batlle A, Muñoz A, Parera V (2009) HFE gene mutations in patients with altered iron metabolism in Argentina. Cell Mol Biol (Noisy-le-grand) 55:3135

36. Pedersen P, Milman N (2009) Genetic screening for HFE hemochromatosis in 6, 020 Danish men: penetrance of $\mathrm{C} 282 \mathrm{Y}$, H63D, and S65C variants. Ann Hematol 88:775-784. doi:10.1007/ s00277-008-0679-1

37. Milward EA, Baines SK, Knuiman MW, Bartholomew HC, Divitini ML, Ravine DG, Bruce DG, Olynyk JK (2008) Noncitrus fruits as novel dietary environmental modifiers of iron stores in people with or without HFE gene mutations. Mayo Clin Proc 83:543-549

38. Pedersen P, Milman N (2009) Extrinsic factors modifying expressivity of the HFE variant C282Y, H63D, S65C phenotypes in 1, 294 Danish men. Ann Hematol 88:957-965. doi:10.1007/ s00277-009-0714-x

39. Heath AL, Fairweather-Tait SJ (2003) Health implications of iron overload: the role of diet and genotype. Nutr Rev 61:45-62

40. Lim EM, Rossi E, De Boer WB, Reed WD, Jeffrey GP (2004) Hepatic iron loading in patients with compound heterozygous HFE mutations. Liver Int 24:631-636. doi:10.1111/j.1478-3231. 2004.0953.x
41. Gurrin LC, Bertalli NA, Dalton GW, Osborne NJ, Constantine CC, McLaren CE et al (2009) HFE C282Y/H63D compound heterozygotes are at low risk of hemochromatosis-related morbidity. Hepatology 50:94-101. doi:10.1002/hep.22972

42. Bérez V, Camps J, Arija V, Aranda N, Fernández-Ballart J, Vilella $\mathrm{E}$ et al (2005) Soluble transferrin receptor and mutations in hemochromatosis and transferrin genes in a general Catalan population. Clin Chim Acta 353:205-208. doi:10.1016/j.cccn. 2004.10.020

43. van der A DL, Peeters PH, Grobbee DE, Roest M, Voorbij HA, van der Schouw YT (2006) HFE genotypes and dietary heme iron: no evidence of strong gene-nutrient interaction on serum ferritin concentrations in middle-aged women. Nutr Metab Cardiovasc Dis 16:60-68. doi:10.1016/j.numecd.2005.07.008

44. Singh M, Sanderson P, Hurrell RF, Fairweather-Tait SJ, Geissler C, Prentice A et al (2006) Iron bioavailability: UK Food Standards Agency workshop report. Br J Nutr 96:985-990

45. Anderson GJ, Darshan D, Wilkins SJ, Frazer DM (2007) Regulation of systemic iron homeostasis: how the body responds to changes in iron demand. Biometals 20:665-674. doi:10.1007/ s10534-006-9030-2

46. Beutler E (2007) Iron storage disease: facts, fiction and progress. Blood Cells Mol Dis 39:140-147. doi:10.1016/j.bcmd.2007. 03.009

47. Whitfield JB, Zhu G, Heath AC, Powell LW, Martin NG (2001) Effects of alcohol consumption on indices of iron stores and of iron stores on alcohol intake markers. Alcohol Clin Exp Res 25:1037-1045

48. Lee SH, Kim JW, Shin SH, Kang KP, Choi HC, Choi SH et al (2009) HFE gene mutations, serum ferritin level, transferrin saturation, and their clinical correlates in a Korean population. Dig Dis Sci 54:879-886. doi:10.1007/s10620-008-0432-6

49. Galan P, Cherouvrier F, Fernandez-Ballart J, Marti-Henneberg C, Hercberg S (1990) Bioavailable iron density in French and Spanish meals. Eur J Clin Nutr 44:157-163 